\title{
Production and validation of educational technology on nursing care for syphilis prevention
}

\author{
Produção e validação de tecnologia educacional sobre cuidados de enfermagem para prevenção da sífilis \\ Producción y validación de la tecnología educativa en cuidados de enfermería para la prevención de la sífilis
}

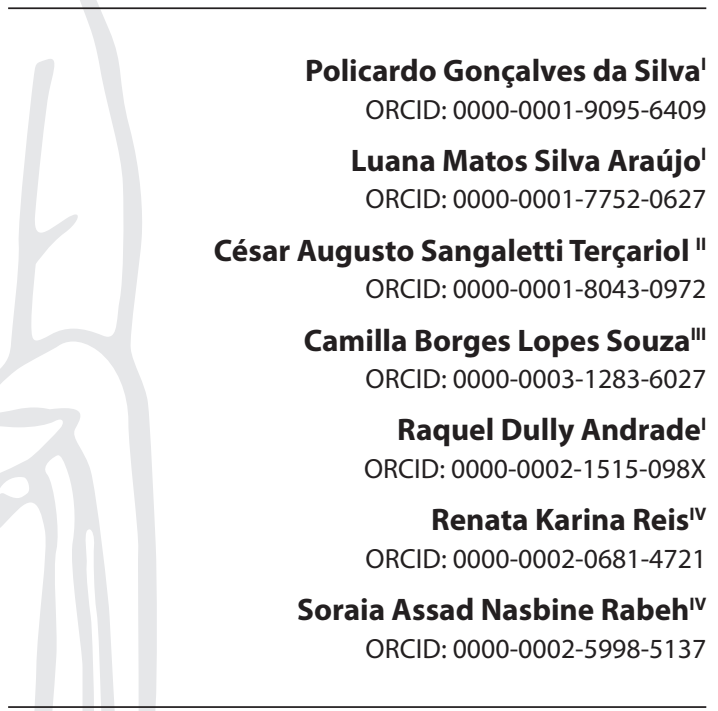

'Universidade do Estado de Minas Gerais. Passos, Minas Gerais, Brazil.

"Centro Universitário Barão de Mauá. Ribeirão Preto,

São Paulo, Brazil.

I"Faculdade de Medicina Atenas. Passos, Minas Gerais, Brazil.

"Universidade de São Paulo. Ribeirão Preto, São Paulo, Brazil.

How to cite this article:

Silva PG, Araújo LMS, Terçariol CAS, Souza CBL, Andrade RD, Reis RK, et al. Production and validation of educational technology on nursing care for syphilis prevention.

Rev Bras Enferm. 2021;74(Suppl 5):e20190694. doi: http://dx.doi.org/10.1590/0034-7167-2019-0694

Corresponding author:

Policardo Gonçalves da Silva

E-mail: goncalvespolicardo@live.com.ar

EDITOR IN CHIEF: Antonio José de Almeida Filho ASSOCIATE EDITOR: Fátima Helena Espírito Santo

\section{ABSTRACT}

Objective: Validate script and storyboard of a video for educational intervention on nursing care for the prevention and management of syphilis. Methods: Methodological design study, with quantitative analysis approach. The content and appearance of the educational video script and storyboard was validated by a committee of experts on the subject and video. They were considered validated from the agreement of $78 \%$, calculated by means of the Content Validity Index. Results: There were suggestions, which were analyzed; and, where relevant, the script and storyboard were changed. The degree of agreement among the expert judges on the subject obtained a Content Validity Index (CVI) of 100\%, while, with the technical experts in video, all the questions in the educational material obtained the percentage above the recommended minimum of $78 \%$. Conclusion: The validated video is an important technological production and could be used in the context of health care. Descriptors: Educational Technology; Sexuality; Self-care; Nursing Care; Syphilis.

\section{RESUMO}

Objetivo: Validar roteiro e storyboard de um vídeo para intervenção educativa sobre assistência de enfermagem visando à prevenção e manejo da sífilis. Métodos: Estudo de delineamento metodológico, com abordagem de análise quantitativa. Foi realizada validação de conteúdo e aparência do roteiro e storyboard do vídeo educativo por um comitê de especialistas na temática e em vídeo. Consideraram-se validados a partir da concordância de 78\%, calculada por meio do Índice de Validade de Conteúdo. Resultados: Houve sugestões, que foram analisadas; e, quando pertinentes, o roteiro e storyboard foram alterados. O grau de concordância entre os juízes especialistas na temática obteve um Índice de Validade de Conteúdo (IVC) de 100\%, enquanto, com os técnicos especialistas em vídeo, todos os quesitos do material educativo obtiveram o percentual acima do mínimo recomendado de $78 \%$. Conclusão: $O$ vídeo validado constitui-se em uma importante produção tecnológica e poderá ser utilizado no contexto da assistência à saúde.

Descritores: Tecnologia Educacional; Sexualidade; Autocuidado; Cuidados de Enfermagem; Sífilis.

\section{RESUMEN}

Objetivo: Para validar el guion y el storyboard de un vídeo para la intervención educativa sobre la asistencia de enfermería que pretende la prevención y el manejo de la sífilis. Métodos: Estudio de la delineación metodológica, con abordaje del análisis cuantitativo. Se realizó la validación del contenido y del aspecto del guion y el storyboard del vídeo educativo para un comité de especialistas en la temática y del vídeo. Se validaron a partir de la concordancia de $78 \%$, calculada por medio del Índice de Validez de Contenido. Resultados: Hubo sugerencias, que se analizaron; $y$, cuando pertinentes, el guion y el storyboard se modificaron. El grado de concordancia entre los jueces especialistas en la temática obtuvo un Índice de Validez de Contenido (IVC) de 100\%, mientras, con los técnicos especialistas en video, todos los quesitos del material educativo obtuvieron el porcentual arriba del mínimo recomendado de $78 \%$. Conclusión: El video validado constituye una importante producción tecnológica y podrá ser utilizado en el contexto de la atención a la salud.

Descriptores: Tecnología Educativa; Sexualidad; Autocuidado; Cuidados de Enfermería; Sífilis. 


\section{INTRODUCTION}

Challenging humanity for several centuries, syphilis has become a major public health problem because it is an infectious disease and leads to systemic involvement when untreated. The infection also significantly increases the risk of contracting the human immunodeficiency virus (HIV), since transmission is facilitated by the presence of syphilitic lesions, and the presence in the body of Treponema pallidum, the etiological agent of syphilis, accelerates the evolution of HIV infection and acquired immunodeficiency syndrome (AIDS) ${ }^{(1)}$.

Since 1986, syphilis has been recognized as a compulsory notification infection throughout the country, through the notification of cases of congenital syphilis by Ordinance No. 542 of December 22, 1986 (2); with the subsequent inclusion of the cases of syphilis in pregnant women with Ordinance n. 33, July 2005(3); and, finally, of the syphilis acquired, by Order No $2472^{(4)}$, published on August 31, 2010 by the Ministry of Health.

The epidemiological relevance of the infection is also highlighted, since in the last five years there has been an increasing increase in the cases of these three types of syphilis: acquired, pregnant and congenital. According to the Mineiro Epidemiological Bulletin (BEM), in 2016 87,593 cases of acquired syphilis, 37,436 cases of syphilis in pregnant women and 20,474 cases of congenital syphilis were reported in Brazil, among them 185 deaths, with the highest proportion of notifications in the Southeast region ${ }^{(5-6)}$.

In the state of Minas Gerais, acquired syphilis has shown an important increase over the years, with prevalence in males: the ratio of sex was 1.8 cases in men for each case in women; and in 2016 , the ratio was 2.1 cases in men for each case in women. In addition, there is a progressive and worrying increase in congenital syphilis from 1.14 cases/thousand live births in 2011 to 5.71 cases/thousand live births in $2016^{(6)}$.

This scenario can be explained in part by the expansion of rapid test coverage, decreased condom use, resistance of health professionals to penicillin administration in Primary Health Care (PHC), worldwide shortage of penicillin, as well as the improvement of the surveillance system in case reporting ${ }^{(7)}$.

In this context, Health Education (HE) constitutes a fundamental element in the promotion of health, as one of the strategies to confront this problem, to be used with the population for the prevention, timely diagnosis and adequate treatment of syphilis, since it strengthens the social participation and autonomy of users ${ }^{(8)}$.

In this sense, the health professional, especially the nurse, has many benefits for being inserted in several services of the health care network, with the possibility of acting to raise awareness and promote behavior change in these individuals and adherence to the follow-up / treatment of syphilis(9).

Among the duties of the nurse, the potential to develop educational activities in order to awaken the desire for transformation and improvement in the quality of life of users, families and communities, based on the sharing of experiences, especially in the context of Primary Health Care (PHC), a priority site for the prevention, diagnosis and treatment of syphilis is highlighted ${ }^{(8-10)}$.

The National Basic Care Policy highlights that health care in $\mathrm{PHC}$ comprises a combination of individual and collective actions aimed at health promotion, prevention of complications, as well as diagnosis and treatment. It is also implemented through the exercise of care and management practices, in a participative way, with the purpose of teamwork, being offered to the populations of defined territories ${ }^{(11)}$.

In view of the above, this study aimed to produce and validate an educational material (video) based on the Clinical Protocol and Therapeutic Guidelines for Comprehensive Care of People with Sexually Transmitted Infections (STIs), of the Ministry of Health, for health promotion, prevention and management of syphilis, targeting the users of health services.

\section{OBJECTIVE}

Validate the script and storyboard of a video for educational intervention on nursing care for the prevention and management of syphilis.

\section{METHODS}

\section{Ethical aspects}

The research was approved by the Research Ethics Committee of the Ribeirão Preto School of Nursing, University of São Paulo (USP), through the Brazil Platform.

\section{Design, study site and period}

It is a methodological study, with a quantitative approach. Methodological studies are aimed at investigating methods for data collection and organization, such as: development, validation and evaluation of research tools and methods, which favors the conduct of research with marked rigor ${ }^{(12)}$.

The production of the educational material (video) was based on the recommendations defined by the Clinical Protocol and Therapeutic Guidelines for Comprehensive Care for People with $\mathrm{STI}^{(6)}$ and a fictitious clinical case. The production of the content was composed of thematic units, initially developed of a script, after whose creation a storyboard was elaborated. It should be noted that the content of the storyboard was the same as the script, following the same division. The storyboard is an organizer, which details the scenes in order to preview the video. This was composed of three columns: 1) audio/narration - all the content of the script was inserted; 2 ) images/scenes - the scenes and shooting locations were described; and 3) in the last column, the pictures/ animations used were described. In this way, the validators had the opportunity to preview the video and carry out their evaluations.

In the descriptions of the storyboard scenes, the simulation was used for the operationalization of the video recording. From the simulation perspective, its type is defined by the fidelity, capacity and logical control of the environment. The first refers to the fidelity of the created domain; the second to the characteristics of the simulated domain; and the third is that which controls the physio-pathological operations of the simulator, based on the pre-programming of the scenario ${ }^{(7)}$. This study did not elaborate classical simulation scenarios, but rather dramatization scripts, with the use of simulators preserving the elements of fidelity, which will be fundamental for the efficiency and effectiveness of the educational intervention aimed at by the video. 
The phases for the construction of the script and storyboard were: Bibliographic search; Visit to the simulation laboratories; Forecast of the consumable material; Forecast of the scenarios; Forecast of the materials to be used ${ }^{(8)}$.

This study is a product of the master's dissertation of the main researcher, entitled: Nursing care for prevention and management of syphilis: validation of educational material ${ }^{(8)}$.

\section{Participants}

The validation of the educational material was carried out by a committee of judges, with researchers and teachers in the areas of HIV/AIDS, educational technologies and/or validation of instruments. The population of this study was composed by a committee of judges specializing in the subject and technical experts in video, being professional nurses and teachers, with clinical experience in the subject and related scientific production. The technicians, video specialists, were the professionals connected to the communication service or related area.

In order to establish parameters for the selection of participants, the following criteria were adopted for the selection of specialists: to have clinical experience; to publish and research on the subject with a minimum score of 5 points - the minimum to be considered as an expert ${ }^{(9)}$. To form the expert committee, a search was carried out on the Lattes Platform of the National Council for Scientific and Methodological Development (CNPq), using the "curriculum search" tool in "advanced search", using the following specifiers: Syphilis; Sexually Transmitted Infections; Doctors; Brazilians; Nurses; be expert in the conceptual framework involved; and have knowledge about construction / evaluation of educational material proven through the Lattes curriculum.

Referring to technical experts in communication and audiovisual, they worked in other related areas, such as editing videos and educational materials, and also communication services with experience in the related area.

The video was recorded in the laboratories of the Nursing Practice Simulation Center, at the Ribeirão Preto College of Nursing, University of São Paulo (EERP / USP).

For the theoretical-practical classes, EERP/USP has five laboratories with several resources, such as audiovisual equipment, low, medium and high fidelity simulators, resources for capture and transmission of synchronous and asynchronous audio and video. These laboratories offer an environment very similar to that of a hospital, home and health unit. They also promote practical training, being basic procedures, since they have static mannequins; and also realistic simulation, because it has high complexity technology (robots).

\section{Data collection}

The data was collected using a script and storyboard content validation tool, with 14 questions, divided into sections related to the socio-demographic and educational characterization of judges and questions related to the objective, content, relevance and environment. The tool used by judges who are experts on the subject and video experts was divided into sections that contained questions relating to functionality, usability and efficiency.
The instrument of validation by the judges specialized in the subject counted on 14 questions, divided in this way: Objective (2 questions); Content (7 questions); Relevance (3 questions); and Environment (2 questions). It was based on the adapted structured tools $s^{(12-13)}$ for the validation of educational material.

In order to validate the script and storyboard, contacts were made via e-mail with the participants of the committee of experts on the theme and video, through an invitation letter with explanations about the research, its objectives, the FICT, as well as the guidelines for filling out the instruments, whose estimated time was approximately 60 minutes, with a forecast return of up to 30 days to the main researcher. To minimize any discomfort regarding time to fill, the participant could extend it if necessary.

Thirteen content specialists were selected, nine of whom responded within the stipulated e-mail response period. For the professional video specialists, seven professionals were selected, and only one of them didn't respond in time.

The quantification of the judges met the recommendation of the literature for the validation of face and content. Six participated, with at least $70 \%$ agreement among them ${ }^{(13)}$. Based on these criteria, a total of 15 participants were recruited, being them: nine judges specialized in the subject as nurses and teachers, with clinical experience in the subject and related scientific production; and six technicians specialized in video, being these, professionals linked to the communication service or related area.

For the pilot study, the adaptation of the instrument was carried out ${ }^{(11)}$. The characterization of the participants included questions about gender, age, current professional area, higher academic degree and participation in scientific event ${ }^{(12-13)}$.

\section{Data analysis}

The collected data were coded and double typed in Excel sheets. After correcting typing errors, they were transported to the analysis in the International Business Machines (IBM) Statistical Package for the Social Sciences (SPSS), version 25.

The descriptive statistical analysis was performed by means of absolute and relative frequencies for the qualitative variables and by means of minimum and maximum values, mean and standard deviation for the quantitative variables.

For each item of the form, the degree of agreement between the judges was calculated by means of the Content Validity Index (CVI). This corresponds to the proportion (in \%) of judges who expressed an "agree" or "partially agree" opinion in relation to the total number of judges, according to Equation 1.

CVI $\frac{{ }^{n} \text { agree }{ }^{n} \text { agree }}{n_{\text {total }}} 100(1)$

For six or more judges, a minimum CVI of $78 \%$ is recommended ${ }^{(13)}$.

The $\mathrm{CVI}$ of each question was calculated as the simple arithmetic mean of the CVIs of the items that compose the question; and the general CVI was calculated as the simple arithmetic mean of the CVIs of all the items that compose the form.

In the video script and storyboard, they were considered validated if there was agreement between the validators of at least $78 \%$, for each item of the instrument. 
The suggestions were analyzed and acted upon as appropriate.

\section{RESULTS}

The production of educational material followed the recommendations defined by the Ministry of Health, through the Clinical Protocol of Clinical and Therapeutic Guidelines for Comprehensive Care for People with Sexually Transmitted Infections 2015 (PCDT/ IST), containing information and language accessible to people seeking care in Basic Health Units (BHU) as well as in the Test and Counseling Center (TCC).

It was divided into Units, as follows:

Unit I - Presentation of the educational video, with initial information such as the title of the video, responsible/authors, place of production, target audience, objectives, estimated time of the video and characters. Unit II - Nursing consultation. Unit III - Essential knowledge for understanding the problem. In this unit, the concepts of syphilis and its implications for health were presented, with emphasis on prevention, stages of infection, treatment and follow-up. Unit IV - Nursing care planning/care plan. Unit V - Nursing interventions for male and female condom handling. Unit VI - Other measures aimed at assisting in the control of syphilis were highlighted in order to provide guidance on prevention, diagnosis and management of infection. The benefits of active participation of the individual and the sexual partnership for the success of the actions were also emphasized. Unit VII - References and credits ${ }^{(8-14)}$.

In all sections, there were suggestions, which were analyzed; and, where relevant, the script and storyboard were changed.

In the first stage, the quantitative results regarding the validation of the script and storyboard will be presented by the judges who are experts in the subject matter and by the technical experts in video.

As for the current professional area of expertise of the judges, eight $(88.9 \%)$ work in the area of nursing teaching, and one (11.1\%) participant is an infectologist doctor working in the area of prevention, diagnosis and treatment of STIs.

The time of professional performance of the specialized judges in the subject varied from one to 34 years, with an average of 16 years (standard deviation of 10.9). In relation to communication specialists and video specialists, the time of performance was seven and 26 years old, with a mean of 15.2 years (standard deviation of 7.7).

As can be seen in Table 1, the CVI obtained 100\% agreement. Most of the responses obtained were "agree" or "partially agree". Only one judge marked the option "disagree" in item 2 of the Relevance question and made the suggestion to verify the question, replacing the ". . nurse in the video. ." by". . user of the video. ..... In both items of the Environment item, the option "agree" was also checked by all the judges. It should be noted that the alternatives "I disagree" and "partially disagree" were not flagged by the judges in the instrument and that, on all items, the majority of the judges marked the answer "I agree".

In the evaluation by expert judges on the subject, all the questions in the educational material obtained an average CVI above the recommended minimum percentage of $78 \%$, as can be seen in Figure 1.
Table 1 - Distribution of the absolute frequency of the level of agreement of the expert judges on the subject $(n=9)$ and the Content Validity Index $(\mathrm{CVI})$ of each item of the validation instrument of the script/storyboard of the educational video, Ribeirão Preto, São Paulo, Brazil, 2018

Question

D PD I PA A $\stackrel{\mathrm{CV} \text { (\%) }}{\mathrm{C}}$ (\%)

Objectives

The objectives are consistent with nursing practice.

The objectives are suitable to be achieved. - $\quad$ - 18100.0

Content

The content presented in the script corresponds to the proposed objectives.

The content facilitates the teaching-

learning process on syphilis prevention and $\quad-\quad$ - $\quad 27100.0$ management.

The content allows understanding of syphilis prevention and management.

The content follows a logical sequence.

$-\quad-27100.0$

The content incorporates all the necessary

steps for the achievement of syphilis

prevention and management.

The content has all the materials necessary to demonstrate prevention and management of syphilis.

The script/script information is correct.

$-\quad-36100.0$

- $\quad$ - 45100.0

$-\quad-\quad 27100.0$

$-\quad-\quad 18100.0$

Relevance

The images and scenes illustrate important

aspects for the practice of syphilis prevention $\quad$ - $\quad$ - $\quad$ - 9100.0 and management.

The images and scenes are relevant for the video user to understand about syphilis prevention and management.

The images and scenes allow the transfer and use of theoretical/practical knowledge in - - $\quad$ - 18100.0 different contexts by the nurses.

Environment

The scenario is suitable for the production of the video.

The setting is suitable for teaching and learning syphilis prevention and management.

Notes: $D=$ disagree, $P D=$ partially disagree, $I=$ indifferent,$P A=$ partially agree, $A=$ agree $C V I=$ content validity index.

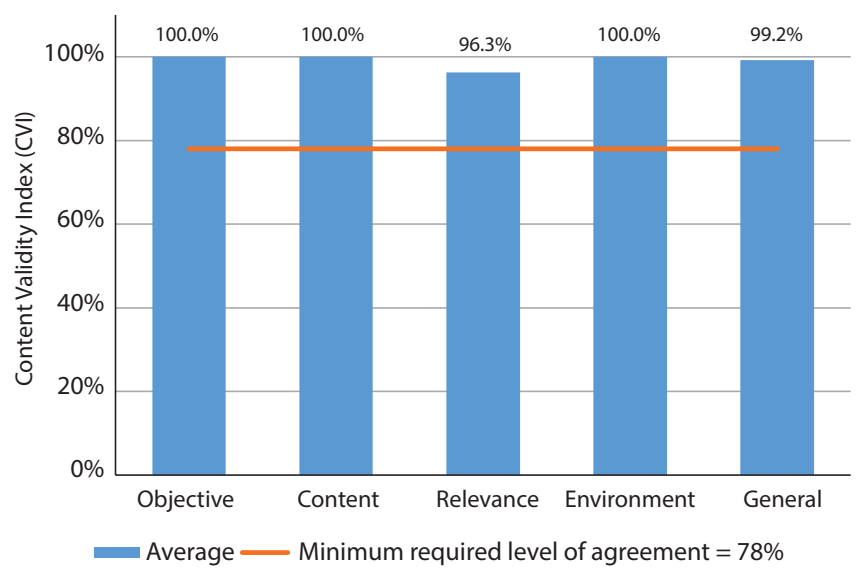

Figure 1 - Content Validity Index (CVI) average by question and general average CVl obtained from the evaluation of the script/storyboard of the educational video by the judges specialized in the subject, Ribeirão Preto, São Paulo, Brazil, 2018 
The validation instrument by the technical video specialists included 10 questions (Table 2), divided into Functionality, containing two questions; Usability, with three questions; and Efficiency, with five questions.

Table 2 - Distribution of the absolute frequency of the level of agreement of the technical video expert judges $(n=6)$ and the Content Validity Index (CVI) of each item of the script/storyboard validation instrument of the educational video, Ribeirão Preto, São Paulo, Brazil, 2018

\begin{tabular}{|c|c|c|c|c|c|c|}
\hline Question & D & PD & I & PA & A & $\begin{array}{l}\mathrm{CVI} * \\
(\%)\end{array}$ \\
\hline \multicolumn{7}{|l|}{ Functionality } \\
\hline $\begin{array}{l}\text { 1) The video script proposes comprehensive } \\
\text { nursing interventions for the prevention } \\
\text { and management of syphilis. }\end{array}$ & - & - & - & - & 6 & 100.00 \\
\hline $\begin{array}{l}\text { 2) The video script has the potential to } \\
\text { generate positive results. }\end{array}$ & - & - & - & 1 & 5 & 100.00 \\
\hline \multicolumn{7}{|l|}{ Usability } \\
\hline $\begin{array}{l}\text { 1) The concepts that will be used in the } \\
\text { video and its applications are easy to learn. }\end{array}$ & - & - & - & 2 & 4 & 100.00 \\
\hline $\begin{array}{l}\text { 2) The video will allow the nurse to learn } \\
\text { about syphilis assessment and prevention } \\
\text { and management interventions, and is easy } \\
\text { to apply. }\end{array}$ & - & - & - & 2 & 4 & 100.00 \\
\hline $\begin{array}{l}\text { 3) The video will help the nurse in a clear } \\
\text { and efficient way, not being tiresome. }\end{array}$ & - & - & 1 & 1 & 4 & 83.33 \\
\hline \multicolumn{7}{|l|}{ Efficiency } \\
\hline $\begin{array}{l}\text { 1) The proposed time is suitable for the } \\
\text { user to learn the content. }\end{array}$ & - & - & - & 2 & 4 & 100.00 \\
\hline $\begin{array}{l}\text { 2) The number of scenes is consistent with } \\
\text { the time proposed for the video. }\end{array}$ & - & - & - & - & 6 & 100.00 \\
\hline $\begin{array}{l}\text { 3) The number and characterization of the } \\
\text { characters meet the proposed objective. }\end{array}$ & - & - & - & 1 & 5 & 100.00 \\
\hline $\begin{array}{l}\text { 4) Communications between characters } \\
\text { occur in an efficient and understandable } \\
\text { manner. }\end{array}$ & - & - & - & - & 6 & 100.00 \\
\hline $\begin{array}{l}\text { 5) The description of the materials to be } \\
\text { used is clear. }\end{array}$ & - & - & - & - & 6 & 100.00 \\
\hline
\end{tabular}

Notes: $D=$ disagree, $P D=$ partially disagree,$I=$ indifferent, $P A=$ partially agree, $A$ = agree, $\mathrm{CVI}=$ content validity index

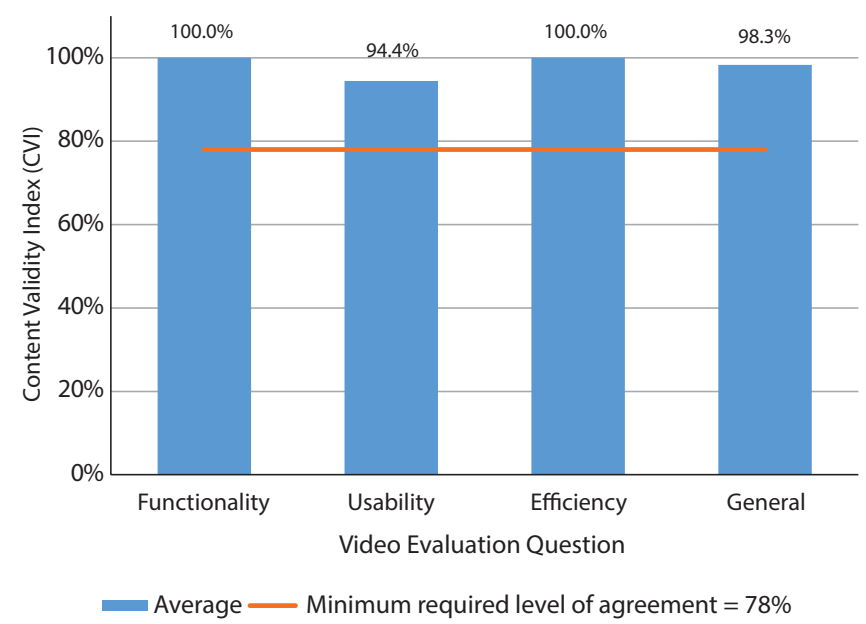

Figure 2 - Content Validity Index (CVI) average by question and general average CVI obtained from the evaluation of the script/storyboard of the educational video by video specialists, Ribeirão Preto, São Paulo, 2018
In the evaluation made by the video specialists, the CVI obtained $100 \%$ of agreement. The alternatives "disagree" and "partially disagree" were not flagged by the judges in the instrument; and in all items of the instrument, most judges marked the answer "I agree".

It should be noted that the alternatives "I disagree" and "partially disagree" were not flagged by the judges in the instrument and that, in all their items, the majority of the judges marked the answer "I agree".

Also, in the evaluation by technical video specialists, all the requirements of the educational material obtained an average $\mathrm{CVI}$ above the recommended minimum percentage of $78 \%$, as can be seen in Figure 2 .

In all sessions of the script and storyboard, there were suggestions, which were analyzed, and the great majority was accepted.

\section{DISCUSSION}

In this study, the script and storyboard were produced by means of a fictitious clinical case, based on clinical practice. It follows the line of research that has sought to rely on real facts experienced in health services, as well as scientific knowledge to create the instruments ${ }^{(14-15)}$.

A similar study was carried out, in which the first version of the script addressed the definition of scenes, lines, environment and audiovisual elements. In addition, the storyboard was composed of visual elements, such as figures, photos and text, relating to the illustrations corresponding to the scenes that composed the video ${ }^{(16)}$.

The construction of the script based on scientific literature is an important step to guide the production of a video, and the storyboard becomes fundamental to guide the creative process in the following stages of production ${ }^{(17)}$.

From this same perspective, other authors describe that the scientific material must be read and analyzed to suit the study, in order to organize the content in modules using the tools of audiovisual animations ${ }^{(17)}$. In addition to organizing the content associated with the theme in a logical manner, it is also necessary to analyze the scenario, the materials and other resources, to specify the details of the narration, photos, figures and scenes of the material in the editing of the educational video ${ }^{(15)}$. Another concern of this study was the audiovisual language to be used, since it is fundamental to arouse interest in the subject and facilitate the understanding of the target audience in order to achieve the objectives proposed with the creation of the educational video. The audiovisual language prevails in the contemporary world, in which the term "audiovisual" refers to the different forms of communication that combine images and sounds, causing a synchrony ${ }^{(18)}$.

The study ${ }^{(19)}$ highlights the diversity of health videos available on the Internet with information that does not match the reality, in addition to the exposure of participants without the proper precepts regarding the rights of images and voice. The choice of the fictitious clinical case was based on a care usually experienced in health services, which refers to exposure and sexual practice without the use of condoms. The fictitious clinical case recordings took place in a simulated outpatient clinical setting. The practice of simulation has been used as an active teaching methodology in order to transmit lived experiences. The participants of this innovative modality are immersed in contexts characterized very close to a real environment. The simulated scenarios can collaborate positively in the production of several materials for the service, such as service protocols, among others ${ }^{(20)}$. 
Scholars complement that simulation, in the context of nursing teaching and learning is a dynamic process involving a hypothetical idea that incorporates a reliable representation of reality. It facilitates connection and integrates the complexities of practical and theoretical learning with the opportunity for repetition, feedback, evaluation and reflection, becoming an important factor in the development of the nurse's decision making process ${ }^{(21)}$. To do so, the choice of complexity or fidelity of the simulated activity depends on the learning objective to be achieved ${ }^{(22)}$. Simulated experience through educational material (video) awakens those who have access both to identifying situations that may be occurring in their environment and to changing behavior ${ }^{(23)}$.

\section{Study limitations}

The clinical validation of educational material with the target public of only one service was considered as a limitation of this study, and it could not be generalized to all population groups. In this way, it is intended to validate it with people of all age groups and from other services.

\section{Contributions to the Nursing area}

The validation and pilot study process allowed the construction of an educational material and technological resource focused on the reality experienced in health services, especially those specialized in STIs. In this sense, their use could provide better knowledge about the various existing prevention technologies, as well as the benefits of these technologies during sexual practices, thus contemplating the self-care of individuals.

\section{CONCLUSION}

The production of educational material (video) has made possible the use of evidence-based practice, which will contribute to health promotion, encouraging the user of the health service in self-care, aiming at the prevention of STIs, especially syphilis. During the nursing consultation, the nurse/actor sought to demonstrate safety, reliability and naturalness in the face of the fictitious clinical case. The user/actor presented his health problem and his concerns considering the bond created in the reception. The principles such as professional secrecy, spontaneous demand and anonymity reinforce the reliability and demystification about prevention through fast testing, availability of prevention inputs in all health units, treatment of infection and its free care throughout the national territory by UHS. It is believed that the educational material (video) may contribute to a better understanding of the issues surrounding the occurrence of syphilis, its prevention, diagnosis and treatment. It will also provide important information for users to choose infection prevention methods, as well as the perception of the benefits of their self-care, with respect to behavior change and safe sexual practices.

\section{AGKNOWLEDGEMENTS}

We thank the Audiovisual Support section and the simulation laboratory team of the Ribeirão Preto Nursing School, University of São Paulo (EERP-USP), for all the support and effective participation throughout the process of characterization of the scenarios, recording and editing of the educational video.

\section{REFERENCES}

1. Ministério da Saúde (BR). Secretaria de Vigilância em Saúde. Departamento de Vigilância, Prevenção e Controle das Infecções Sexualmente Transmissíveis, do HIV/Aids e das Hepatites Virais. Protocolo Clínico e Diretrizes Terapêuticas para Profilaxia Pré-Exposição (PrEP) de Risco à Infecção pelo HIV [Internet]. Brasília: Ministério da Saúde; 2018 [cited 2019 Apr 10]. Available from: http://www.aids.gov.br/system/tdf/ pub/2016/64510/miolo_pcdt_prep_11_2018_web.pdf?file=1\&type=node\&id=64510\&force=1

2. Vieira FS, Potela NLC, Sousa GC, Costa ES, Oliveira DEP, Neiva MJLM. Interrelationship of health education actions in the context of the family health strategy: nurses' perceptions. Rev Pesqui: Cuid Fundam. 2017;9(4):1139-14. doi: 10.9789/2175-5361.2017.v9i4.1139-1144

3. Silva FM, Budó MLD, Girardon-Perlini NMO, Garcia RP, Sehnem GD, Silva DC. Contributions of health education groups to the knowledge of people with hypertension. Rev Bras Enferm. 2014;67(3):347-53. doi: 10.5935/0034-7167.20140045

4. Ministério da Saúde (BR). Boletim Epidemiológico. Secretaria de Vigilância em Saúde. Sífilis 2017 [Internet]. 2017 [cited 2019 Apr 10];23;48(36):144. Disponível em: http://portalarquivos.saude.gov.br/images/pdf/2017/novembro/13/BE-2017-038-Boletim-Sifilis-11-2017-publicacao-.pdf

5. Lima DVM. Research design: a contribution to theauthor. O Braz J Nurs [Internet]. 2011 [cited 2019 Apr 10];10(2). Available from: http:// www.objnursing.uff.br/index.php/nursing/article/view/3648/html_2

6. Ministério da Saúde (BR). Secretaria de Vigilância em Saúde. Departamento de DST, Aids e Hepatites Virais. Protocolo Clínico e Diretrizes Terapêuticas para Atenção Integral às Pessoas com Infecções Sexualmente Transmissíveis [Internet]. Brasília: Ministério da Saúde; 2015 [cited 2019 Apr 10]. Available from: http://bvsms.saude.gov.br/bvs/publicacoes/protocolo_clinico_diretrizes_terapeutica_atencao_ integral_pessoas_infeccoes_sexualmente_transmissiveis.pdf

7. Brandão CFSB, Collares CF, Marin HF. [Realistic simulation as an educational tool for medical students]. Sci Med Internet [Internet]. 2014 [cited 2019 Apr 10];24(2):187-92. Available from: http://revistaseletronicas.pucrs.br/ojs/index.php/scientiamedica/article/ view/16189/11485 Portuguese

8. Silva PG. Assistência de enfermagem para prevenção e manejo da sífilis: validação de material educativo [Dissertação] [Internet]. Ribeirão Preto: Universidade de São Paulo, Escola de Enfermagem de Ribeirão Preto; 2018 [cited 2019 Apr 10]. doi:10.11606/D.22.2018. tde-21092018-140548 
9. Fehring JR. Methods to validate nursing diagnoses. Hert Lung [Internet]. 1987 [cited 2019 May 10];16(6):625-29. Available from: https://pdfs. semanticscholar.org/11f7/d8b02e02681433695c9e1724bd66c4d98636.pdf

10. Rabeh SAN, Gonçalves MBB, Caliri MHL, Nogueira PC, Miyazaki MY. [Construction and validation of a virtual educational module for topical treatment of chronic wounds]. Rev Enferm UERJ [Internet]. 2012[cited 2019 May 10];20(esp.1):603-8. Available from: https://www.e publicacoes.uerj.br/index.php/enfermagemuerj/article/view/5819 Portuguese.

11. Campoy LT. Reabilitação intestinal de indivíduos com lesão medular: produção de material para intervenção educativa [Dissertação] [Internet]. Ribeirão Preto: Universidade de São Paulo, Escola de Enfermagem de Ribeirão Preto; 2015 [cited 2019 May 10]. doi:10.11606/D.22.2016.tde-28012016-155419.

12. Campoy LT, Rabeh SAN, Castro FFS, Nogueira PC, Terçariol CAS. Bowel rehabilitation of individuals with spinal cord injury: video production. Rev Bras Enferm. 2018;71(5):2376-82. doi: 10.1590/0034-7167-2017-0283

13. Pasquali L. Teoria e métodos de medida em ciências do comportamento. Brasília: Laboratório de Pesquisa em Avaliação e Medida/Instituto de Psicologia/UnB: INEP; 1996. 432p.

14. Polit DF, Beck CT. Using research in evidence-based nursing practice. In: Polit DF, Beck CT, editors. Essentials of nursing research. Methods, appraisal and utilization. Philadelphia (USA): Lippincott Williams and Wilkins; 2006. p.457-94.

15. Braga FTMM, Garbin LM, Marmol MT, Khouri VY, Vasques Cl, Carvalho EC. Oral hygiene in chemotherapy patients: construction and validation of an educational vídeo. Rev Enferm UFPE. 2014;8(10):3331-9. doi: 10.5205/reuol.6039-55477-1-ED.0810201411

16. Ferreira MVF, Godoy S, Góes FSN, Rossini FP, Andrade D. Lights, camera and action in the implementation of central venous catheter dressing. Rev Latino-Am Enfermagem. 2015;23(6):1181-6. doi: 10.1590/0104-1169.0711.2664

17. Lima MB, Rebouças CBA, Castro RCMB, Cipriano MAB, Cardoso MVLML, Almeida PC. Construction and validation of educational video for the guidance of parents of children regarding clean intermittent catheterization. Rev Esc Enferm USP. 2017;51:e03273. doi: 10.1590/ S1980-220X2016005603273

18. Frota NM, Barros LM, Araújo TM, Lopes MVO, Almeida PC, Caetano JA. Validation of educational hypermedia about peripheral venipuncture. Texto Contexto Enferm. 2015;24(2):353-61. doi: 10.1590/0104-07072015003480013

19. Silva AC, Seki JTP, Pereira RSG. A videoaula enquanto recurso audiovisual na educação matemática: A construção de uma proposta a partir de avaliações diagnósticas. Rev Tecnol Educação [Internet]. 2016 [cited 2019 May 10];(14):1-14. Available from: http://tecedu.pro.br/wpcontent/uploads/2016/07/Art7-vol14-jul2016-A-videoaula-enquanto-recurso-audivisual-na-educa\%C3\%A7\%C3\%A3o-matem\%C3\%A1ticaA-constru\%C3\%A7\%C3\%A3o-de-uma-proposta-de-uma-proposta-a-partir-de-avalia\%C3\%A7\%C3\%B5es-diagn\%C3\%B3sticas.pdf

20. Pereira KDC, Cogo ALP, Silva APSSD. Critical analysis of peripheral catheter venipuncture videos available on youtube. Rev Min Enferm. 2016;20:e970. doi: 10.5935/1415-2762.20160040

21. Pazin Filho A, Scarpelini S. Simulation: definition. Medicina [Internet]. 2017 [cited 2019 Jun 27];40(2):162-6. doi: 10.11606/issn.2176-7262. v40i2p162-166

22. Costa RR, Medeiros SM, Vitor AF, Lira ALBC, Martins JCA, Araújo MS. Types and purposes of the simulation in undergraduate nursing education: integrative literature review. Rev Baiana Enferm. 2016;30(3):1-11. doi:10.18471/rbe.v30i3.16589

23. Mazzo A, Martins JCA, Baptista RCN, Godoy S, Coutinho VRD, Seixas CA, et al. A Simulação e a Videoconferência no Ensino de Enfermagem. Rev Graduação USP. 2017;2(2):55-63. doi:10.11606/issn.2525-376X.v2i2p55-63 